Fall 2011

\title{
Smart Sanctions Revisited
}

C. Joy Gordon

Fairfield University, jgordon@fairfield.edu

Follow this and additional works at: https://digitalcommons.fairfield.edu/philosophy-facultypubs

Copyright 2011 Carnegie Council for Ethics in International Affairs

http://dx.doi.org/10.1017/S0892679411000323

\section{Peer Reviewed}

\section{Repository Citation}

Gordon, C. Joy, "Smart Sanctions Revisited" (2011). Philosophy Faculty Publications. 18.

https://digitalcommons.fairfield.edu/philosophy-facultypubs/18

\section{Published Citation}

Gordon, J. "Smart Sanctions Revisited," Ethics and International Affairs, Vol. 25, No. 3, Fall 2011, p.315-335.

This item has been accepted for inclusion in DigitalCommons@Fairfield by an authorized administrator of DigitalCommons@Fairfield. It is brought to you by DigitalCommons@Fairfield with permission from the rightsholder(s) and is protected by copyright and/or related rights. You are free to use this item in any way that is permitted by the copyright and related rights legislation that applies to your use. For other uses, you need to obtain permission from the rights-holder(s) directly, unless additional rights are indicated by a Creative Commons license in the record and/or on the work itself. For more information, please contact digitalcommons@fairfield.edu. 


\section{Smart Sanctions Revisited Joy Gordon*}

$\mathrm{T}$ argeted sanctions-often referred to as "smart sanctions"-began in large measure as a response to the UN Security Council sanctions imposed on that the sanctions on Iraq, initially welcomed by antiwar activists as a peaceful alternative to military action, were different from any sanctions seen before. Combined with the destruction from the bombing campaign of the Gulf War, they were devastating to the Iraq economy and infrastructure, resulting in widespread malnutrition, epidemics of water-borne diseases, and the collapse of every system necessary to ensure human well-being in a modern society. As the sanctions seemed to have no end in sight, there was considerable "sanctions fatigue" within the United Nations, as well as a growing body of literature that questioned whether sanctions were effective at obtaining compliance by the target state, even when there was considerable impact on its economy.

In the wake of these concerns, there were efforts in many venues to design sanctions that would not have the humanitarian impact of broad trade sanctions, and that would also be more effective by putting direct pressure on individual national policy-makers. These targeted sanctions included arms embargoes, financial sanctions on the assets of individuals and companies, travel restrictions on the leaders of a sanctioned state, and trade sanctions on particular goods. Many viewed targeted sanctions as an especially promising tool for foreign policy and international governance, and many still see targeted sanctions as a natural and obvious solution to a broad array of difficult situations. But there are considerable difficulties with each type of targeted sanction, with regard to implementation, humanitarian impact, and, in some cases, due process rights. Some of these difficulties may be

${ }^{*}$ I would like to thank George Lopez, the anonymous reviewers, and the editors of this journal for their very helpful comments on an earlier draft of this article. I am also grateful for research support from the National Endowment for the Humanities, Fairfield University, and the Global Justice Program in the MacMillan Center for International and Area Studies at Yale University.

Ethics \& International Affairs, 25, no. 3 (2011), pp. 315-335.

(C) 2011 Carnegie Council for Ethics in International Affairs

doi:10.1017/So892679411000323 
resolved as these measures continue to be refined. Others are rooted in fundamental conflicts between competing interests or intractable logistical challenges.

\section{The Problem of Humanitarian Impact}

Between World War II and 1990 no one thought much about the humanitarian impact of economic sanctions. There was little visible humanitarian damage, because sanctions were never devastating; and they were not devastating because they were never comprehensive. During the cold war, if the United States sanctioned a country, that country could trade with the Eastern bloc, and vice versa. Consequently, sanctions were sufficiently limited in scope that they raised no concerns for human rights. Nor did the Security Council impose comprehensive measures, since it was largely paralyzed, also because of the cold war. As a result, with rare exceptions, there was little concern for the humanitarian impact of sanctions. On the contrary, in the 1980 os the Security Council sanctions on South Africa, accompanied by a broad global movement for divestment, were seen as a nonviolent but effective component of the struggle against apartheid. To the extent that they worsened the economic conditions for the black population of South Africa, this was generally not seen as a critical ethical failing of the sanctions, especially as many black South African leaders supported boycotts and divestment in solidarity with the antiapartheid movement.

But beginning in 1991 and continuously for the next twelve years, the negative humanitarian impact of the sanctions on Iraq was steadily reported by UN agencies, such as UNICEF and the World Health Organization, as well as such nongovernmental organizations as the International Committee of the Red Cross. These various bodies documented the continuing nature of the crisis, including epidemics of cholera and typhoid, widespread malnutrition, the deterioration of the national health care system, severe shortages of electricity, and the collapse of public and private transportation. While Saddam Hussein was often blamed, by the mid-1990s it became clear that the sanctions were also in large measure responsible for the massive, indiscriminate human damage. ${ }^{1}$

Prior to 1990 the sanctions literature had little to say about humanitarian impact. For the most part, the scholars and practitioners who looked at sanctions were interested in their effectiveness, defined as the likelihood that the target state would comply with the demands made by those imposing the sanctions. Such was the case with the two editions of Economic Sanctions Reconsidered, a study that 
measured the effectiveness of more than a hundred uses of sanctions in the twentieth century. ${ }^{2}$ Other studies considered a reconfiguration of the measure of effectiveness, with David Baldwin arguing that sanctions should be deemed effective as long as they created costs that were a factor in the calculus of decision-making by the target state. ${ }^{3}$ Still others looked at the question of how to maintain a coalition of nations participating in a sanctions regime, as each nation was losing opportunities for trade. There were discussions of the range of possible purposes of sanctions, with Margaret Doxey articulating a broad list, including symbolism and expression of disapproval, as well as persuading the targeted state to change its practices. $^{4}$

The Iraq sanctions, however, triggered a considerable backlash, and sanctions were suddenly viewed in a very different light. UN Secretary-General Boutros Boutros-Ghali described economic sanctions as a "blunt instrument" that raises "the ethical question of whether suffering inflicted on vulnerable groups in the target country is a legitimate means of exerting pressure on political leaders whose behaviour is unlikely to be affected by the plight of their subjects." ${ }^{5}$ In 1994, in an address to the UN General Assembly, Cornelio Sommaruga, the president of the International Committee of the Red Cross, asked, "Is it not incongruous to impose debilitating sanctions with one hand while with the other bringing in humanitarian aid to restore supplies vital to the population's survival?"6

By the mid-1990s there was much more attention paid, on several fronts, to the humanitarian problems associated with sanctions, and numerous proposals were made to implement procedures that would limit their human damage. Among them, in 1995, Boutros-Ghali proposed establishing a mechanism such that prior to imposing sanctions there would be an assessment of their potential impact, and they would be monitored to minimize the collateral damage. ${ }^{7}$ In 1996 the Organization for Security and Co-operation in Europe (OSCE) held a review of the various sanctions that had been imposed by the Security Council on the former Yugoslavia. The OSCE roundtable "gave considerable attention to the need to reduce the negative humanitarian effect of sanctions on the civilian population," and proposed that the Council incorporate measures that would allow humanitarian goods to reach civilians. ${ }^{8}$

UN consultants were retained to review the implementation of Security Council sanctions and to make recommendations to address their humanitarian impact. One set of consultants, based at the Watson Institute at Brown University and at the Kroc Institute at the University of Notre Dame, produced the report 
"Toward More Humane and Effective Sanctions Management: Enhancing the Capacity of the United Nations System." Published in October 1997, the report recommended gauging the humanitarian impact of sanctions through the monitoring of public health indicators, such as malnutrition and child mortality; economic indicators, such as the availability of essential goods; population indicators, such as refugees; and the effect of sanctions on governance and civil society, via such indicators as increased crime or political repression. ${ }^{9}$ As the academic literature on sanctions grew, it came to include not only studies by political scientists but also by public health experts and aid workers who had encountered the issue of humanitarian damage first-hand. ${ }^{10}$

The criticism of the humanitarian impact of sanctions was so extensive that, after Iraq, there were only two other occasions when the Security Council imposed broad trade sanctions: on Haiti (1993-1994) and the former Yugoslavia (19921995). Beginning in the early 1990 s the sanctions regimes imposed by the Security Council, as well as the European Union, were narrower and more refined, and some of the recommendations for monitoring and preliminary assessments were implemented. In the case of Iraq, for example, there was an extensive system for monitoring the humanitarian crisis; and the UN Department of Humanitarian Affairs conducted a preliminary review in February 1997 of the possible humanitarian effects of imposing a flight ban on Sudan. ${ }^{11}$

It was in this context that the concept of "smart sanctions" was developed. Comprehensive sanctions, and their indiscriminate impact, were to be replaced with targeted sanctions, designed to affect only the leadership of the target country, or to restrict goods used by the leadership to engage in aggression or human rights violations.

\section{The Smart Sanctions Movement}

The process of articulating and refining the various types of targeted sanctions took place on many levels. George Lopez of the Kroc Institute and David Cortright of the Fourth Freedom Forum provided singular leadership in the field of targeted sanctions: serving as consultants to the Security Council and to NGOs, publishing influential collections in the field, working with practitioners, and arranging conferences and other forums that provided opportunities for scholars from many disciplines to contribute their expertise. ${ }^{12}$ In addition, the Watson Institute's Targeted Sanctions Project sponsored workshops and conferences, 
conducted studies on financial sanctions, worked with many national governments, and provided advice to the Security Council and other UN bodies. There were also numerous studies by other researchers and consultants, as well as workshops to develop better methods of implementation involving academics, NGOs, government officials, and UN representatives. For example, in 1996 the Carnegie Commission on Preventing Deadly Conflict issued a report articulating the need for targeted sanctions: "Sanctions should be part of a broader influence strategy that puts maximum political and economic pressure as precisely as possible on the offending parties-preferably regimes or specific leaders, rather than whole populations.... But even sharper measures are possible. 'Targeted' sanctions offer a way to focus the penalty more directly on those most responsible for the crisis." 13 Similarly, the Watson Institute and the Council on Foreign Relations organized roundtable discussions on the feasibility of financial sanctions. The first of these, "Banking, Crime, and Economic Sanctions," was convened in New York in May 1998 and brought together key academics, government officials, UN practitioners, and banking officials for an initial discussion of the feasibility of targeted financial sanctions, and a second meeting was held the following month. ${ }^{14}$ In December of the same year there was a symposium on targeted sanctions sponsored by eight nongovernmental organizations, also held in New York; ${ }^{15}$ as well as a London conference sponsored by the Overseas Development Institute (ODI), ${ }^{16}$ which then produced a report titled "Can Sanctions Be Smarter? The Current Debate." ${ }^{17}$

In 1998 and 1999 the Swiss government facilitated a series of discussions on targeted financial sanctions, known as the Interlaken Process. It examined the scope of targeted financial sanctions, as well as the legal and administrative structures for their implementation. The Interlaken Process, in which the banking industry played a major role, began by looking at the tools for dealing with money laundering. Using financial sanctions in the context of Chapter VII of the UN Charter presented an additional question: How does the Security Council devise effective financial measures when it will be national governments that must implement them? The initial concern was whether states would be willing to implement these Security Council measures. The second Interlaken session followed up by looking at the question of how states could implement them, given disparities among states in their administrative and legal capacities. ${ }^{18}$

The meetings produced a manual for practitioners and a white paper by the Watson Institute's Targeted Financial Sanctions Project. ${ }^{19}$ In 1999 and 2000 
there was also a series of expert seminars and working groups, sponsored by the German foreign office, the UN Secretariat, and the Bonn International Center for Conversion, known as the Bonn-Berlin Process, that focused on arms embargoes and sanctions related to travel. They developed model resolutions and made recommendations regarding arms export policies and the monitoring and enforcement of arms embargoes. ${ }^{20}$

In April 2000 the International Peace Academy sponsored a conference in New York, entitled "Toward Smarter, More Effective UN Sanctions." In November of that year UN Secretary-General Kofi Annan, in an address to the International Rescue Committee, invoked the need for smart sanctions: "If we want to punish, let us punish the guilty. And if we want to bring about change, let us target the powerful, not the powerless." ${ }^{21}$ A few months later, during a visit to the Middle East in February 2001, Secretary of State Colin Powell proposed the use of smart sanctions in Iraq, which eventually culminated in the development of a fairly precise list of prohibited goods and significantly reformed the Iraq sanctions regime. ${ }^{22}$ In October 2001 the International Peace Academy held a policy forum entitled "Targeted Sanctions: New Initiatives," in conjunction with a special session of the Security Council regarding sanctions. ${ }^{23}$ This in turn was followed by the Stockholm Process, an initiative of the Swedish Ministry for Foreign Affairs and Uppsala University. It consisted of a series of meetings over the course of 2002, involving more than a hundred experts, to facilitate the use of sanctions that are effective, humane, and targeted. ${ }^{24}$ The findings were presented to the Security Council in February 2003. The Stockholm Process was followed by the creation of the Special Program on the Implementation of Targeted Sanctions, which continues to operate today, sponsored by Uppsala University.

In addition to these initiatives, the UN began establishing panels of experts to monitor arms embargoes, conducting extensive field visits, and drawing on the expertise of their members in weapons, illicit trade, and the particular region involved. These panels are housed in the UN's Department of Political Affairs, although they work closely with the Security Council committees established to monitor the sanctions regimes imposed under Chapter VII. The groups of experts have made a number of recommendations to refine the language of the Council's resolutions, as well as the methods and goals of arms embargoes.

Thus, considerable effort has gone into formulating targeted sanctions that would be more effective in influencing the decision-making of political leaders, 
or would more successfully prevent the flow of the goods that are themselves a source of escalating conflict, while avoiding harm to civilian populations or to third parties. There have been successes in many instances, and significant refinement and improvements in implementation.

\section{Revisiting Targeted Sanctions}

In 2002, Arne Tostensen and Beate Bull methodically reviewed the various types of targeted sanctions, looking at the difficulties associated with their effectiveness, implementation, and legality. They attributed some of the problems to lack of experience in implementation, and to underdevelopment of the political or administrative systems involved. ${ }^{25}$ However, almost a decade later there are still problems that remain unresolved. Some of these difficulties are also found in the use of broader trade sanctions; others are specific to targeted sanctions. With some measures, there are logistical problems with implementation; with others, even when the measures are implemented, there is little effect on the policy of the target state; and with some, the targeted measures in fact are overbroad, triggering the same sort of humanitarian problems for the civilian population that characterized trade sanctions. In addition, over the last decade, as there has been greater use of financial blacklists against individuals and companies, there have also emerged questions of due process in their use.

\section{Arms Embargoes}

Arms embargoes can seek to block the flow of arms to an entire country, to particular groups or areas within a country, or to particular individuals or groups, wherever they are. From the United Nations' inception until 1990 the Security Council imposed arms embargoes only twice, against South Africa and Rhodesia (now Zimbabwe). In the decade that followed, the Council imposed arms embargoes a dozen more times.

Arms embargoes seem like an ideal example of a targeted sanction, in that they are intended to interrupt the flow of precisely those goods that will escalate a conflict or facilitate a human rights abuse. But while there has been considerable refinement in their use, there continue to be substantial practical problems in implementation. Most significantly, studies have indicated that arms embargoes actually do little to reduce the flow of weapons. ${ }^{26}$ On the contrary, the prohibition creates a black market for weapons, accompanied by opportunities for higher profits than in the legal arms trade. There are systematic ways to circumvent 
the prohibitions, such as the use of "flags of convenience" to disguise a ship's or an aircraft's country of origin, the filing of false air routes by cargo planes, and the forgery of end-user certificates. ${ }^{27}$ There is often collusion of multiple state actors. For example, in the case of arms trafficking to Liberia, numerous East European countries exported the illicit arms, while several West African states facilitated illegal shipments. ${ }^{28}$

The sheer quantity of weapons available globally makes it virtually impossible to suppress the flow of arms anywhere. One commentator on smart sanctions notes that "the world is literally awash in arms." ${ }^{29}$ Multiple studies have found that arms embargoes do not significantly reduce the flow of arms-they just make them more expensive; $3^{\circ}$ and "the higher the extra cost of weapons, the more attractive the illegal deals." ${ }^{1}$ There is greater success in restricting the sale of major weapons systems, since these are more likely to be produced by state enterprises and be subject to stricter controls. ${ }^{32}$ Indeed, in the case of Iraq the absence of weapons of mass destruction and the overall deterioration of the Iraqi military were testaments to the success of the sanctions, insofar as their goal was containment. However, light weapons can more easily be manufactured and sold by private companies. Embargoes have little effect on their availability, and light weapons are the ones most commonly used in recent armed conflicts. ${ }^{33}$

In addition to the potential profit available from illicit trafficking, the effectiveness of an arms embargo depends heavily on neighboring countries monitoring commercial traffic and enforcing the restrictions-often countries that may have neither the capacity nor the will to do so. In states where illicit arms are manufactured and exported, there needs to be control over private actors, and for this the state needs an efficient bureaucracy, good border controls, and the consistent punishment of violators. ${ }^{34}$ This is particularly pressing in light of the rise of transnational criminal networks and their role in arms sales.

The panels of experts mandated to monitor the arms embargoes often comment on these issues in their reports. For example, the panel monitoring the embargo on Côte d'Ivoire noted that for several reasons, "even with extensive presence in the country, there are difficulties in monitoring and enforcement," pointing out that some military units would not allow UN forces to conduct inspections. ${ }^{35}$ Many of the letters sent by the panel of experts to the government ministries seeking information were not answered; and this was also the case for their requests for information sent to a number of other national governments, as well as international businesses and organizations. ${ }^{36}$ The panel of experts for the sanctions 
imposed on North Korea noted in 2010 that more than a hundred member states had not reported on their implementation of the sanctions as they are required to do, or had submitted late reports. The panel attributed this to "a lack of resources, a lack of experience, a lack of awareness, insufficient understanding, different national priorities, and time-consuming inter-agency procedures." ${ }^{37}$

The panel of experts for the arms embargo imposed on Liberia observed that there were numerous ways that arms traffickers were able to avoid detection, including false flight plans, forged registration documents, and false declarations on cargo manifests. ${ }^{38}$ In addition, they noted that "the borders of Liberia remain porous and are characterized by multiple informal entry points. The Panel notes that, as a result, there is great potential for trafficking in arms and ammunition between Liberia and Côte d'Ivoire." 39 Similarly, in Somalia the experts observed that "sea transport has become the choice for the continued violations of the arms embargo," given the ease and cost-effectiveness. They reported that there was also significant overland shipment of weapons, across borders and within the country. ${ }^{40}$

Given the difficulties of effectively curtailing the flow of arms, it is not surprising that arms embargoes rarely result in any actual changes in the behavior of the target state. A 2007 study by SIPRI, the Swedish research institute on armed conflicts, found that in twenty-seven cases involving mandatory arms embargoes, the behavior of the target state improved only a quarter of the time. ${ }^{41}$ Michael Brzoska gives an even lower figure: in a study of seventy-four arms embargoes operating between 1990 and 2005, he finds that the target state changed its policy only 8 percent of the time. ${ }^{42}$ (Brzoska, however, considers three types of effectiveness in the context of arms embargoes: target compliance; reduction of arms flow; and satisfaction of the sender. While target compliance is quite low, effectiveness defined by the two other categories is much higher. In 39 percent of the cases, the flow of arms is reduced; and in 31 percent of the cases the sender is satisfied with the outcome, even if the target has not complied. ${ }^{43}$ Brzoska uses this reasoning to argue that arms embargoes should be seen as more effective than mere target compliance would suggest.)

Arms embargoes are sometimes undermined even by allies of the state imposing them. That can be true even if the allies are permanent members of the Security Council, who themselves voted to impose the embargo. For example, during the arms embargo on the former Yugoslavia, a U.S. company, MPRI, provided weapons to Bosnia. In the case of Sierra Leone, a British company, Sandline 
International, provided covert shipments of arms to the exiled government, in violation of the embargo. ${ }^{44}$ Indeed, according to a study by SIPRI, in about two-thirds of the mandatory arms embargoes imposed by the United Nations from 1990 to 2006 the illicit weapons that arrived in the embargoed areas were primarily manufactured by the permanent members of the Security Council. ${ }^{45}$ Arms embargoes are also easily circumvented by any country that already has an industrial base, since other types of manufacturing can be converted to weapons production. This conversion can in fact result in increased income and economic growth. ${ }^{46}$

Aside from the problems of implementation and effectiveness, arms embargoes have sometimes raised questions of ethics and equity. An arms embargo that is applied equally to both sides of a conflict can in fact have the effect of putting one side at a significant disadvantage, with the wrongdoer benefiting and the vulnerable side put in an even worse position. In the case of the former Yugoslavia, the arms embargo against all the parties to the conflict in practice meant, at least initially, that the Serbian Yugoslav People's Army held most of Yugoslavia's weapons and controlled most of its arms industry, while the Croats were put an enormous disadvantage. This was a significant contributing factor in the genocide against the Bosnian Muslims. ${ }^{47}$ The Security Council has since refined its practice, permitting arms shipments to regimes it considers legitimate, although the country as a whole remains under an arms embargo.

\section{Travel Sanctions}

There are two common types of travel sanctions: those limiting travel by individuals, such as visa bans, and those involving broader restrictions, such as flight bans or restrictions on an entire airline.

Visa bans seem to be an ideal targeted measure in that they can designate individual political leaders or wrongdoers by name, and the restrictions would affect them alone. But there are problems with implementation, and doubts whether those targeted are seriously affected. Often there are no clear procedures providing guidance for states that encounter banned individuals in their territory or attempting to enter it. It is not difficult for individuals to hold passports in multiple nationalities or to use fraudulent passports. But even when the travel of individuals can effectively be restricted, there is little evidence that it is so costly to a political or military leader as to cause him to reconsider a policy or state practice, or 
that restricting travel affects such individuals in any way that goes beyond inconvenience. ${ }^{48}$

Aviation bans target an airline or a nation's airline industry. In some cases, such as the sanctions imposed on Libya in response to the Lockerbie bombing, the aviation ban was widely viewed as contributing to a successful outcome. However, there continue to be difficulties with implementation and enforcement of aviation bans; and, as with any measure that compromises something as fundamental as transportation, there are significant consequences for the civilian population, for neighboring countries, and for others who are not the intended subject of the sanction.

Even when there are extensive efforts to strengthen them, there are many ways that flight bans can be circumvented. Planes can be registered under different names, and the pilots can file false flight plans. Restrictions on passenger flights are implemented relatively well, since commercial passenger airlines are generally well regulated; however, the air cargo industry is not, and thus aviation bans on cargo flights are quite porous. ${ }^{49}$ These illegal flights, in turn, often contribute to the black market in the sanctioned country. The flight ban imposed on the National Union for the Total Independence of Angola (UNITA) was violated continuously, with tons of goods being flown in daily on illegal but highly profitable flights, benefiting those who could afford to buy black market goods. ${ }^{50}$

There are also humanitarian impacts that are not widely acknowledged. The lack of regular commercial flights can significantly affect the population as a whole. The flight ban imposed on commercial flights to and from Haiti in 1994 was seen as a way of denying the wealthy the opportunity to shop for luxuries abroad, but another consequence was that hundreds of Haitians hoping to receive asylum in the United States or elsewhere had no way to leave the country. ${ }^{51}$ In the case of the Security Council sanctions on Libya in response to Lockerbie, the aviation ban meant that travel presented a much greater hardship for the population as a whole; for example, a flight from Tripoli to Alexandria, Egypt, is only ninety minutes, whereas driving takes fifteen hours. ${ }^{52}$

Restrictions on aviation do more than block flights carrying elites on shopping trips or cargo flights bringing in luxuries. Aviation is critical to other sectors, such as agriculture and health care. UN agencies reported that the aviation ban in Libya compromised the import of agricultural inputs and veterinary supplies, and also undermined crop dusting, which in turn reduced the availability of food from both animal sources and agriculture. ${ }^{53}$ When the Security Council assessed the expected humanitarian impact of sanctions on Sudan, UN agencies anticipated 
that an aviation ban would affect medical evacuations and the import of vaccines that require refrigeration, as well as food availability, since aviation bans were likely to undermine the import of perishable goods. ${ }^{54}$

In addition to prohibiting flights, aviation bans often also prohibit the sale of parts or services related to aircraft maintenance. Consequently, even where there are exemptions-for local travel, crop dusting, or medical evacuations-the secondary prohibitions can undercut those exemptions. In Libya, domestic air travel was compromised by safety issues, since the air travel ban prohibited the sale of parts for repair and maintenance, and prohibited services, such as engineering or the certification of airworthiness. ${ }^{55}$ In Afghanistan, the Security Council sanctions froze the assets of the state-owned airline, depriving it of the funds to purchase spare parts for repair and maintenance. ${ }^{56}$ This measure ignored the fact that air travel is critical in Afghanistan, since fighting and the consequent damage to roads and bridges makes overland travel dangerous.

\section{Targeted Trade Sanctions}

Targeted trade sanctions seek to interrupt the flow of particular commodities, such as timber, diamonds, or oil, on the grounds that they benefit political or military leaders responsible for human rights abuses or aggression. In some cases, they are designed to work in conjunction with other sanction measures. For example, since Liberia used timber taxes to purchase arms, the Security Council prohibited the import of Liberian lumber. ${ }^{57}$ But to the extent that the export of a particular commodity can be undermined, if it is a significant part of the target state's economy, there can also be the problem of overbreadth that characterized the Iraq sanctions: that is, compromising a significant export may interrupt the cash flow of the leadership, but it may also damage a sector of the economy. As a result, legitimate business can be affected; and by undermining the state's source of funding, it can also deprive the state of the funds needed to perform legitimate governmental functions.

As with the other types of targeted sanctions, there are logistical difficulties with implementation. Commodities are often fungible, and it may be impossible to identify whether a particular shipment of timber or oil came from the sanctioned state. Even if there are certification procedures, they are often not standardized, or they lend themselves to forgery. As with arms embargoes, interrupting the flow of a commodity may simply result in new transport routes to circumvent monitors.

In the case of conflict diamonds, some of the critical problems of implementation-and the problem of overbreadth-were addressed through the Kimberly 
Process, in which the diamond industry worked with importing and exporting governments and the Security Council to develop a system of certificates of origin to ensure that illicit diamonds were effectively blocked from entering the market. This allowed the diamond industry to avoid blanket measures that would have affected diamond sales overall. It should be noted, however, that the diamond industry is a multibillion-dollar concern that was well positioned to lobby at the highest levels to protect its interests. Most individuals or companies, or for that matter entire populations, do not have the leverage or the global reach to develop comparable measures that will protect their interests while allowing for the enforcement of a trade sanction.

\section{Financial Sanctions}

There are three general types of financial sanctions: those that blacklist particular persons or companies; those that blacklist certain categories of persons, such as senior military officers; and blanket measures targeting a state or broad group, with a "white list" of companies and individuals that are exempt.

It has been difficult to assess the effectiveness of financial sanctions in particular, since they have almost always been imposed in conjunction with other types of sanctions. ${ }^{58}$ However, there are ongoing issues with regard to their effective implementation, and there are also problems concerning the impact on third parties. Implementation issues are considerable, given that action must be taken quickly and secretly lest the targeted individual has time to move those assets beforehand. But, as one commentator notes, it is in the nature of international sanctions that prompt and secret decisions are unlikely. ${ }^{59}$ Implementing financial sanctions also requires an extensive institutional and technological capacity. In the United States, the Treasury Department's Office of Foreign Assets Control has such a capacity, but it is unusual in this regard. The burden on banks is also substantial. One commentator noted that a major New York bank typically processed 115,000 transactions per day, and 2.3 million fund transfers per month. Over one month, the interdiction software might typically tag 27,000 transactions as potentially illicit, and all of those would then have to be examined further. ${ }^{60}$

Financial sanctions are implemented more easily in banking than in other areas, in part because banks are already a highly regulated industry, and because banking transactions predominantly involve electronic transfers, or electronically recorded transactions. But outside the banking industry, implementation of financial sanctions is much more difficult to coordinate, even where businesses are willing to 
comply. For example, there is "the McDonald's problem"-that is, if all U.S. nationals are prohibited from transacting business with al-Qaeda, does that mean that McDonald's is expected to refrain from selling a hamburger to anyone associated with al-Qaeda? If so, what procedures should McDonald's be expected to put in place to monitor its transactions, so as to avoid the inadvertent sale of a Quarter Pounder to a blacklisted terrorist? ${ }^{61}$

Freezing the assets of individuals, companies, and foundations is seen as one of the most promising forms of targeted sanctions, on many levels. The lists of designated terrorists or human rights violators embody the sense of precision and the intuitive sense of fairness that make the idea of targeted sanctions so compelling. Freezing an individual's assets also seems far more forceful and damaging than, say, travel restrictions. However, there are logistical difficulties with this measure as well: a corrupt dictator can hide his assets abroad in the same ways as a criminal involved in drug trafficking or money laundering. For asset freezes to be implemented, the leader of a target state must have identifiable assets abroad, and the leader must be more interested in retaining his wealth than in exercising power. Even when a leader's assets can be located, asset freezes are most likely to be effective in limited circumstances: where the target nation is a poor country and the leader has few other options for acquiring wealth; and where the sender is only demanding modest changes that do not threaten the regime's ability to hold power. $^{62}$

While some financial measures were used against South Africa, interrupting the access of South African enterprises to foreign banks, the first targeted financial sanctions in the 1990 s were imposed on General Raoul Cedras of Haiti, in 1994. The first blacklists of individuals and companies whose assets were to be frozen were drawn up in 1998, in the sanctions regime imposed on Angola and the listing of individuals and entities related to UNITA. ${ }^{63}$ Initially, the primary issues with asset freezes concerned logistical problems of implementation. The legitimacy of these measures was largely unquestioned in the 1990s, as they were used in situations where there was little doubt that their targets, such as Slobodan Milošević, constituted a threat to peace and security. However, the use of asset freezes increased dramatically after September 11, 2001, when the United States added some 200 names to the lists of those sanctioned under Security Council Resolution 1267 for their putative involvement with Osama bin Laden, al-Qaeda, and the Taliban. This marked a shift not only in the quantity of those targeted but in the criteria for inclusion on the lists. Whereas earlier asset 
freezes had been imposed on persons or entities that had contributed to aggression or breaches of peace, the lists compiled in regard to terrorism were in many cases preventive measures-targeting the assets of those with no criminal history who had not yet committed any wrongful act. Consequently, while the lists of designated individuals and companies seem quite precise, they have also been controversial.

As with any other Chapter VII measure, financial sanctions are imposed as part of a political process, without the constitutional safeguards of a criminal prosecution or the transparency of civil litigation, and the 1267 regime has given rise to concerns about due process. Some of those listed have brought legal proceedings against the national governments and the European Community, which implemented the measure; and in response to the legal actions, the Security Council has developed some limited forms of recourse. ${ }^{64}$ Resolution 1267 itself provided no means for those listed to challenge their inclusion; neither did it allow for humanitarian exemptions. Initially, any member could propose names for the list, and if there was no objection from other member states within forty-eight hours, the names were added. Further, the proposing government was not required to provide any information supporting its claims. If a listed individual's government was willing to, it could approach the members of the Security Council and ask for the individual's removal from the list; and if the Council agreed unanimously, then he would be removed. However, if the individual's government did not want to undertake this diplomatic effort, or if it was unsuccessful, the listed individual had no further recourse.

The 1267 regime has been widely criticized, and there have been repeated efforts at reform. In March 2006 the UN's Office of Legal Affairs released a study concluding that the Council should adopt "fair and clear procedures" for the blacklists, which would include the right of the individual to be informed of the measures taken against him; the right to be heard by a body of the Council within a reasonable time; and the right to seek an effective remedy before an impartial body. ${ }^{65}$ In June 2006 the secretary-general asked the Council to establish fair and clear procedures for its blacklists, in both its procedures for inclusion and for "delisting." ${ }^{66}$ In August 2006 the UN special rapporteur on human rights criticized the lack of due process for those on the sanctions blacklists. ${ }^{67}$ Still, it was not until December of that year that the Security Council established a procedure to notify those who had been blacklisted and provide them with a brief statement of the reasons they had been targeted, and established an office (the "focal point") 
to perform the clerical function of receiving and distributing petitions by those who disputed their inclusion on the blacklist. ${ }^{68}$ The focal point offered no advocacy; and neither did it establish an impartial body that could hear evidence and determine whether blacklisting was appropriate in individual cases.

Criticism of the 1267 regime continued to be widespread, and scathing. By 2007 more than fifty nations had raised concerns about its arbitrariness and deprivation of due process rights. ${ }^{69}$ In 2009 the International Commission of Jurists issued a report on counterterrorism measures and human rights, in which it found the measures of the 1267 regime to be arbitrary, discriminatory, and "unworthy" of the United Nations. ${ }^{70}$ However, the reforms subsequently adopted by the Security Council continued to fall far short of the rule of law or international standards for civil rights and due process. In late 2009 the Security Council replaced the focal point with an ombudsperson who would actually meet with petitioners and would advocate for them before the committee. ${ }^{71}$ This was still a far cry, though, from an impartial tribunal that could provide an effective remedy in the event of abuses by the Council.

One of the individuals that the United States added in the aftermath of September 11 was a Saudi businessman, Yassin Abdullah Kadi. In December 2001 he brought an action before the European Court of Justice (ECJ), challenging the EU's implementation of Resolution 1267. Although there have been legal actions before other national and regional judicial bodies, the Kadi case has been particularly significant. In 2008 the ECJ ruled on the case, annulling the EU's regulations implementing the Security Council 1267 list on the grounds that the EU is still bound to observe fundamental human rights, even when implementing Security Council resolutions under Chapter VII. ${ }^{72}$ The EU then revised its procedures, sending Kadi a summary of the reasons for his inclusion on the list, and inviting him to provide comments or information in response. The EU dismissed his subsequent response, and continued to maintain a freeze on his assets. The most recent ruling on the case, issued by the General Court of the EU in September 2010, ${ }^{73}$ found that the EU's practices still did not provide an adequate review of Kadi's claims, and again annulled the regulations implementing Resolution $1267 .^{74}$

Within the procedures available, a number of individuals have been successfully "delisted," and the number of those adversely affected by the lists is relatively small. Nevertheless, these cases have raised important questions about the boundaries of the Council's Chapter VII powers. Whereas the early rulings from the ECJ 
as well as domestic courts held that a member state was unequivocally obligated to implement a Chapter VII measure without objection or appeal, the later rulings have begun to suggest that a member state may not have an unequivocal duty to implement Chapter VII measures automatically; and, further, that the Council may be limited in its actions in these circumstances by principles of international law. Of all the types of targeted sanctions, asset freezes may raise the most serious questions for international law regarding the limits of global governance.

\section{Conclusion}

There was considerable optimism in the 1990 about the possibilities of smart sanctions. Many expected them to provide an elegant and powerful solution to the failings of broad economic sanctions. They seemed like the perfect fixhard-hitting measures, affecting only those responsible for terrorism or international law violations, and without the ethical and humanitarian problems that come from crippling an economy. Certainly, enormous efforts have gone into refining targeted sanctions to improve their effectiveness and to resolve the human rights problems that have emerged. But while targeted sanctions are more politically palatable than broad sanctions, they continue to be problematic on many levels.

Several types of targeted sanctions, such as arms embargoes, have structural problems with implementation that appear to be irresolvable after almost two decades of efforts by practitioners, NGOs, and academics. Most types of smart sanctions have not brought about an increase in effectiveness that is dramatically better than that of "traditional" broad trade sanctions. Some have argued that effectiveness has to be understood more broadly than just target compliance. As noted earlier, Baldwin maintains that sanctions should be seen as effective if they increase the costs to the targeted actor or otherwise affect the calculus of decision-making. Adopting a different approach, Brzoska suggested that, in the case of arms embargoes, while target compliance was very low, arms embargoes could be considered much more successful if we look instead at situations where the sender is satisfied with the outcome, regardless of actual compliance.

There may be merit to Baldwin's and Brzoska's strategies for evaluating the impact of sanctions. However, they do not support the view that, because they aim at specific individuals or goods, targeted sanctions are significantly more effective than traditional trade sanctions. These proposals only suggest that if 
we use different criteria, we will view sanctions as more successful than they seem by the measurement of target compliance. But that is equally true of traditional sanctions. And, as Drezner notes, however "smart" the sanctions are, their effectiveness is compromised when the senders have different goals. One sender can be looking for containment, another for regime change; or one sender's goals can change as its strategic interests in the region change, without any goal being accomplished. ${ }^{75}$ To the extent that targeted sanctions are imposed to achieve conflicting or ambiguous goals, they will be no more effective than traditional sanctions.

More disappointingly, targeted sanctions did not bring an end to the humanitarian damage or the ethical conundrums presented by traditional trade sanctions-at least not in the manner expected. Arms embargoes that are imposed against all parties-both aggressors and victims-can cripple the self-defense efforts of those under attack. Aviation bans can undermine a major component of a nation's transportation sector, adversely affecting the civilian population generally. Financial sanctions targeting the personal assets of individuals-the form of targeted sanctions that is often seen as the most promising in every regard-has raised issues of due process that have brought into question the fundamental nature of the Council's authority to impose Chapter VII measures.

It may even be that the rhetoric of targeted sanctions has caused, so to speak, a certain collateral damage: it seems that the trend toward designing-or at least labeling-economic measures as "targeted" has done much to silence the discussion of the humanitarian impact. Where the 1990s witnessed growing demands that humanitarian monitoring be incorporated within the sanctions regime, and for prior assessment of the humanitarian impact, this has largely ceased. It seems that the common view is that since sanctions are now "smart," we no longer have to worry about harming the innocent. But that is clearly not the case. Sanctions targeting a nation's financial system, or critical industries or exports, disrupt the economy as a whole, much like traditional trade sanctions.

In the end, targeted sanctions are successful in part; in some ways unsuccessful, or at least no more successful than traditional sanctions; and in at least one case, the UN's targeted list of alleged terrorists, they raise a new set of problems. Thus, while targeted sanctions have not brought about the kind of catastrophe that characterized the Iraq sanctions in the early 1990s, they are still fraught with many of the same difficulties and failures that characterized their not-so-smart predecessors. 
${ }^{1}$ See, e.g., Claudia von Braunmühl and Manfred Kulessa, "The Impact of UN Sanctions on Humanitarian Assistance Activities: Report on a Study Commissioned by the United Nations Department of Humanitarian Affairs" (Berlin: Gesellschaft für Communication Management Interkultur Training mbH-COMIT, 1995).

${ }^{2}$ Gary Clyde Hufbauer et al., Economic Sanctions Reconsidered: History and Current Policy (Washington, D.C.: Institute for International Economics, 1985); and Gary Clyde Hufbauer et al., Economic Sanctions Reconsidered, 2nd ed. (Washington, D.C.: Institute for International Economics, 1990).

${ }^{3}$ David A. Baldwin, Economic Statecraft (Princeton, N.J.: Princeton University Press, 1985).

${ }^{4}$ Margaret P. Doxey, International Sanctions in Contemporary Perspective (Basingstoke, Hampshire: Macmillan, 1987).

${ }^{5}$ Boutros Boutros-Ghali, Report of the Secretary-General on the Work of the Organization, "Supplement to an Agenda for Peace: Position Paper of the Secretary-General on the Occasion of the Fiftieth Anniversary of the United Nations," A/50/60 - S/1995/1, January 3, 1995, para. 70.

${ }^{6}$ Cornelio Sommaruga, "Strengthening the Coordination of Emergency Humanitarian Assistance: Humanitarian Policy and Operational Activities," Address at the United Nations General Assembly, 49th session, November 23, 1994, in International Review of the Red Cross, no. 304 (February 28, 1995).

7 Boutros-Ghali, Report of the Secretary-General, "Supplement to an Agenda for Peace," para. 75.

${ }^{8}$ UN Security Council, "Letter Dated 24 September 1996 from the Chairman of the Security Council Committee Established Pursuant to Resolution 724 (1991) Concerning Yugoslavia Addressed to the President of the Security Council," S/1996/776, September 24, 1996, p. 16, para. 95.

${ }^{9}$ Watson Institute for International Studies, "Toward More Humane and Effective Sanctions Management: Enhancing the Capacity of the United Nations System," Occasional Paper 31, 1988, p. vi.

${ }^{10}$ For example, David Cortright and George A. Lopez, eds., Economic Sanctions: Panacea or Peacebuilding in a Post-Cold War World? (Boulder, Colo.: Westview Press, 1995); and Thomas G. Weiss et al., eds., Political Gain and Civilian Pain: Humanitarian Impacts of Economic Sanctions (Lanham, Md.: Rowman \& Littlefield Publishers, 1997).

${ }^{11}$ Watson Institute, "Toward More Humane and Effective Sanctions Management," p. v.

12 David Cortright and George A. Lopez, eds., Smart Sanctions: Targeting Economic Statecraft (Lanham, Md.: Rowman \& Littlefield, 2002); www.sanctionsandsecurity.org/.

13 "Preventing Deadly Conflict," Final Report, Carnegie Commission on Preventing Deadly Conflict, Carnegie Corporation of New York, pp. 54-55; www.wilsoncenter.org/subsites/ccpdc/pubs/rept97/ finfr.htm.

${ }^{14}$ Watson Institute, Targeted Financial Sanctions Project; www.watsoninstitute.org/tfs/targetedfinsan. $\mathrm{cfm}$.

15 United Nations Secretariat, Department of Political Affairs, "The Experience of the United Nations in Administering Arms Embargoes and Travel Sanctions," in Michael Brzoska, ed., Smart Sanctions: The Next Steps (Baden-Baden: Nomos Verlagsgesellschaft, 2001), p. 46.

${ }^{16}$ Ibid.

17 Koenraad Van Brabant, Overseas Development Institute, "Can Sanctions Be Smarter? The Curent Debate" (Report of a Conference Held in London December 16-17, 1998), May 1999; www.seco. admin.ch/themen/00513/00620/00639/00641/index.html?lang=en.

${ }_{18}$ Thomas Biersteker et al., "Consensus from the Bottom Up? Assessing the Influence of the Sanctions Reform Processes," in Peter Wallensteen and Carina Staibano, eds., International Sanctions: Between Words and Wars in the Global System (New York: Frank Cass, 2005), p. 17.

19 Watson Institute for International Studies, "Targeted Financial Sanctions: A Manual for Design and Implementation: Contributions from the Interlaken Process," 2001.

${ }^{20}$ Michael Brzoska, ed., Design and Implementation of Arms Embargoes and Travel and Aviation Related Sanctions: Results of the 'Bonn-Berlin Process' (Bonn, Ger.: Bonn International Center for Conversion, 2001).

${ }^{21}$ United Nations Secretariat, "The Experience of the United Nations in Administering Arms Embargoes and Travel Sanctions," p. 46.

${ }^{22}$ David Cortright et al., "Smart Sanctions in Iraq: Policy Options," in Cortright and Lopez, eds., Smart Sanctions: Targeting Economic Statecraft, p. 202. This was known as the "Goods Review List," established by Resolution 1409, which went into effect in summer 2002.

${ }^{23}$ Watson Institute, Targeted Financial Sanctions Project; www.watsoninstitute.org/tfs/targetedfinsan. cfm.

${ }^{24}$ Special Program on the Implementation of Targeted Sanctions (SPITS), the "Stockholm Process"; www. smartsanctions.se/. 
${ }^{25}$ Arne Tostensen and Beate Bull, “Are Smart Sanctions Feasible?” World Politics 54, no. 3 (April 2002), pp. 373-403.

${ }^{26}$ Peter Wallensteen et al., Making Targeted Sanctions Effective: Guidelines for the Implementation of UN Policy Options (Uppsala, Swed.: Uppsala University, 2003), p. 105.

${ }^{27}$ Maraike Wenzel and Sami Faltas, "Tightening the Screws in West African Arms Embargoes," in Michael Brzoska and George A. Lopez, eds., Putting Teeth in the Tiger: Improving the Effectiveness of Arms Embargoes (Bingley, England: Emerald Publishing, 2009), p. 115.

${ }^{28}$ Ibid., p. 111.

29 "Introduction: Assessing Smart Sanctions: Lessons from the 1990s," in Cortright and Lopez, eds., Smart Sanctions: Targeting Economic Statecraft, p. 15.

${ }^{30}$ Peter Wallensteen et al., p. 105.

${ }^{31}$ Michael Brzoska, "Putting More Teeth in UN Arms Embargoes," in Cortright and Lopez, eds., Smart Sanctions: Targeting Economic Statecraft, p. 128.

${ }^{32}$ Michael Brzoska, "A Framework for the Analysis of the Effectiveness of Arms Embargoes," in Brzoska and Lopez, eds., Putting Teeth in the Tiger, p. 12.

${ }^{33}$ Michael Brzoska, "A Brief Background on the 'Bonn-Berlin Process,"” in Brzoska, ed., Smart Sanctions: The Next Steps, p. 11.

${ }^{34}$ Brzoska, "A Framework for the Analysis of the Effectiveness of Arms Embargoes," p. 12.

35 "Report of the Group of Experts on Cote d'Ivoire on the Implementation of Paragraph 2 of Security Council Resolution 1761 (2006)," S/2007/611, October 17, 2007, para. 29.

36 "Letter Dated 7 October 2009 from the Chairman of the Security Council Committee Established Pursuant to Resolution 1572 (2004) Concerning Côte d'Ivoire Addressed to the President of the Security Council," S/2009/521, October 29, 2009, para. 15, para. 11.

37 "Letter Dated 12 May 2010 from the Panel of Experts Established Pursuant to Resolution 1874 (2009) Addressed to the President of the Security Council," S/2010/571, November 5, 2010, para. 36.

38 "Letter Dated 7 October 2002 from the Panel of Experts on Liberia to the Chairman of the Committee Established Pursuant to Resolution 1343 (2001) Concerning Liberia," S/2002/1115, para. 62.

39 "Letter Dated 30 November 2008 from the Panel of Experts on Liberia Addressed to the Chairman of the Security Council Committee Established Pursuant to Resolution 1521 (2003)," S/2008/785, December 17, 2008, p. 4.

40 "Letter Dated 14 February 2005 from the Members of the Monitoring Group on Somalia Addressed to the Chairman of the Security Council Committee Established Pursuant to Resolution 751 (1992)," $\mathrm{S} / 2005 / 153$, para. 13 , para. 14 .

${ }^{41}$ Damien Fruchart et al., Stockholm International Peace Research Institute, "United Nations Arms Embargoes: Their Impact on Arms Flows and Target Behaviour" (SIPRI and Uppsala University, 2007), p. x. In a subcategory of six cases, there was some improvement in the actions of the target state immediately before and after the imposition of arms embargoes, in five of six cases studied. Ibid., p. 46. However, it is difficult to identify the direct cause of the changes, since in most cases the arms embargoes are accompanied by other measures, including other types of sanctions. In the five cases where there were "standalone" arms embargoes, one study found that there was little or no impact: Cortright and Lopez, eds., Smart Sanctions: Targeting Economic Statecraft, p. 24. Cortright and Lopez "Targeted Sanctions: Lessons from the 1990s," in Brzoska, Smart Sanctions: Next Steps, p. 24

${ }^{42}$ Michael Brzoska, "A Quantitative Analysis of Arms Embargoes," in Brzoska and Lopez, eds., Putting Teeth in the Tiger, p. 207.

${ }^{43}$ Ibid.

${ }^{44}$ Loretta Bondi, "Arms Embargoes: In Name Only?" in Cortright and Lopez, eds., Smart Sanctions: Targeting Economic Statecraft, p. 112.

${ }^{45}$ Fruchart et al., "United Nations Arms Embargoes," p.24.

${ }_{46}$ Brzoska, "Putting More Teeth in UN Arms Embargoes," p. 127.

47 Kimberly Ann Elliott, "Analyzing the Effects of Targeted Sanctions," in Cortright and Lopez, eds., Smart Sanctions: Targeting Economic Statecraft, p. 174; and Brzoska, "Putting More Teeth in UN Arms Embargoes," p.130.

48 Anthonius W. de Vries, "EU Sanctions against Yugoslavia, 1998-2000" in Cortright and Lopez, eds., Smart Sanctions: Targeting Economic Statecraft, p. 99.

49 Richard W. Conroy, "The UN Experience with Travel Sanctions: Selected Cases and Conclusions," in Cortright and Lopez, eds., Smart Sanctions: Targeting Economic Statecraft, p. 162.

${ }^{50}$ Ibid., pp. 153-54.

${ }^{51}$ Ibid., pp. 156-57.

52 Ibid., p. 149. 
53 Ibid., pp. 149, 163.

54 Ibid., p. 160; and Kimberly Ann Elliott, "Analyzing the Effects of Targeted Sanctions," p. 173.

${ }_{55}$ Richard W. Conroy, “The UN Experience with Travel Sanctions.”, p. 147.

${ }^{56}$ Ibid., p. 158.

57 UN Security Council Resolution 1521 (2003).

58 "Introduction," in Cortright and Lopez, eds., Smart Sanctions, p. 10.

59 David Cortright et al., "Targeted Financial Sanctions That Do Work," in Cortright and Lopez, eds., Smart Sanctions: Targeting Economic Statecraft, p. 29.

${ }^{60}$ Ibid., p. 34.

${ }^{61}$ Peter Fitzgerald, "Compliance Issues Associated with Targeted Economic Sanctions," in House of Lords, Select Committee on Economic Affairs, 2nd Report of Session 2006-07, The Impact of Economic Sanctions, Vol. II: Evidence, p. 150.

62 Elliott, "Analyzing the Effects of Targeted Sanctions," p. 179.

${ }_{63}^{6}$ UN Security Council Resolution 1173 (1998).

${ }^{64}$ See Yvonne Terlingen, “The United States and the UN's Targeted Sanctions of Suspected Terrorists: What Role for Human Rights?" Ethics \& International Affairs 24, no. 2 (Summer 2010), pp. 131-42.

${ }^{65}$ Bardo Fassbender, "Targeted Sanctions and Due Process: The Responsibility of the UN Security Council to Ensure That Fair and Clear Procedures Are Made Available to Individuals and Entities Targeted with Sanctions under Chapter VII of the UN Charter," Study Commissioned by the United Nations Office of Legal Affairs, Office of Legal Counsel, March 20, 2006, p. 8, para. 12.

${ }^{66}$ Kofi Annan, non-paper written to the United Nations Security Council referenced by Under-Secretary General for Legal Affairs Nicola Michel in his address to the United Nations Security Council, Proceedings of 5474th Meeting, S/PV.5474 (2006), p. 5.

${ }^{67}$ UN General Assembly, "Report of the Special Rapporteur," A61/27 (2006), para. 34.

${ }^{68}$ UN Security Council Resolution 1730 (2006).

${ }^{69}$ Andrew Hudson, "Not a Great Asset: the UN Security Council's Counter-Terrorism Regime: Violating Human Rights," Berkeley Journal of International Law, Vol. 25, No. 2 (2007), p. 123.

${ }^{70}$ International Commission of Jurists, "Assessing the Damage, Urging Action: Report of the ICJ Eminent Jurists Panel on Terrorism, Counterterrorism and Human Rights," February 27, 2009, pp. 116-17.

${ }^{71}$ UN Security Council Resolution 1904 (2009).

${ }^{72}$ Yassin Abdullah Kadi and Al Barakaat International Foundation v Council and Commission, C-402/05 P and C-415/05 P, judgment of September 3, 2008, par. 326.

${ }^{73}$ Formerly known as the Court of First Instance.

${ }^{74}$ Kadi v European Commission, Judgment of the General Court, September 30, 2010, T-85/09, para. 149.

75 Daniel Drezner, "How Smart Are Smart Sanctions?" International Studies Review 5 (2003), pp. 107-110. 